\title{
Determinants of Knowledge of Occupational Hazards among Workers in Automobile Assembly Plants
}

\author{
Azuike EC ${ }^{1}$, Egenti BN ${ }^{2}$, Njelita $\mathrm{IA}^{3}$, Nwachukwu CC $\mathrm{CH}^{3}$, Obi-Okaro $\mathrm{AC}^{4}$, \\ Ilika $\mathrm{AL}^{4}$, Azuike $\mathrm{ED}^{5}$ \\ ${ }^{1}$ Foundation for Health and Development in Nigeria \\ ${ }^{2}$ Department of Community Medicine, University of Abuja/University of Abuja Teaching Hospital, \\ Abuja, Nigeria \\ ${ }^{3}$ Department of Community Medicine, Chukwuemeka Odumegwu Ojukwu University/ University \\ Teaching Hospital, Akwa, Nigeria \\ ${ }^{4}$ Department of Community Medicine, Nnamdi Azikiwe University/University Teaching Hospital, \\ Nnewi, Nigeria \\ ${ }^{5}$ Department of Nursing Sciences, Nnamdi Azikiwe University, Awka, Nigeria
}

\begin{abstract}
:
Background: Protecting the health of workers cannot be achieved without the workers having adequate knowledge of hazards and safety measures in their workplace. Knowledge of these hazards and safety measures can be affected by several factors. Discovering the factors that affect knowledge will help in instituting measures to ensure that the workers have adequate knowledge. Aim: This study was conducted as a sequel to an earlier study. Its aim was to determine factors affecting knowledge of the automobile assembly plant workers regarding occupational hazards and safety measures in their workplace. Methods: This is a cross-sectional descriptive study. Data were collected using quantitative methods. A semi-structured, pre-tested, intervieweradministered questionnaire was used to obtain information from the respondents. Data were analyzed with the SPSS version 20 software and summarized using proportions and means, and were presented in tables for easy appreciation. Chi-square test was used to test for association between categorical variables. A p-value of $<0.05$ was considered statistically significant. Results: Out of the 318 respondents, 50 (15.7\%) were workers in Plant B, while 268 (84.3\%) were workers in Plant A. There were 308 (96.9\%) males and only 10 (3.1\%) females. The commonest age group was the 26-30 years age group, 119 (37.4\%) while the least common age group was the 36-40 years age group 5 (1.6\%). The mean age was 27.88 years with a standard deviation of \pm 7.28 years. There were 229 (72.0\%) single respondents, while 86 (27.0\%) were married. Majority of the respondents had secondary education 299 (94.0\%), while 19 (6.0\%) had tertiary education. None of the respondents had no formal education. The proportion 141 (44.3\%) have worked for 3 to 4 years. Only $3(0.9 \%)$ respondents have worked for 5 to 6 years. The mean number of years of working in the companies was 3.62 years ( \pm 4.07 years). There was no statistically significant association between age and knowledge regarding occupational hazards. There was no statistically significant association between marital status and knowledge regarding occupational hazards. There was no statistically significant association between age and knowledge regarding safety measures. Also there was no statistically significant association between marital status and knowledge regarding safety measures. Conclusion: This study has revealed that age and marital status were not determinants of knowledge regarding occupational hazards and safety measures among automobile assembly workers. Further studies should be carried out on possible determinants of knowledge of occupational hazards and safety measures among automobile assembly workers.
\end{abstract}

Keywords: Determinants, knowledge, occupational hazards, safety measures, automobile assembly workers.

\section{INTRODUCTION}

The effect of occupational diseases on the lives of workers and their families cannot be overemphasized. Occupational diseases cause huge suffering and losses to workers, businesses, social security funds and societies at large. ${ }^{1}$ It is estimated that there are globally about 2.02 million deaths annually caused by diseases due to work, while the annual global number of cases of non-fatal work related diseases is estimated to be 160 million. ${ }^{2}$ Globally, more than half of countries do not provide statistics for occupational diseases and there is little capacity for workers' health surveillance, 
according to the International Labour Organization (ILO). ${ }^{1}$ Occupational injuries have been said to account for more than 10 million DALYs and $8 \%$ of unintentional injuries worldwide. ${ }^{3}$ The ILO estimates that about $4 \%$ of Gross Domestic Product (GDP) worldwide is lost because of work-related diseases and injuries. ${ }^{4}$

According to the WHO Global Health Risks estimates,more than 350,000 workers lose their lives each year due to unintentional occupational injuries. ${ }^{5}$ Also $8 \%$ of the total burden of unintentional injuries in men is attributable to work-related injuries in high income countries, and $18 \%$ in low and middle income countries.

In sub-Saharan Africa alone, ILO estimates 257,000 work-related fatalities including about 55,000 injuries. ${ }^{6}$ These health outcomes provoke a loss of roughly $4 \%$ of GDP due to workers' compensation, lost work days, interruption of production, retraining, medical expenditures and so on, not even counting the suffering and poverty caused in the families by those deaths and diseases. ${ }^{7}$

In the automobile industry, workers are exposed to several hazards including: high noise levels, excessive heat, physical injuries like cuts, lacerations and amputations, inhalation of chemicals which cause respiratory problems and cancers, chemical burns, inhalation of welding fumes, heavy metals poisoning such as lead, musculoskeletal problems, eye problems from welding, skin problems etc., ${ }^{8,910}$ Several studies have highlighted the occupational hazards of the automobile industry: A study done in an automobile manufacturing company in China reported that the noise level exceeded the standard and $35.58 \%$ of the workers had hearing impairment and $15.05 \%$ had pneumoconiosis. ${ }^{11}$ Another study in an automobile assembly plant in Iran reported that $31.4 \%$ of the workers had acquired colour vision defect due to exposure to neurotoxic chemicals. ${ }^{12} \mathrm{~A}$ case control study at another automobile assembly company in Iran reported that the welders in the company had higher prevalence of chronic bronchitis than controls who were office workers, also the welders had lower pulmonary function levels with a dose-effect relationship and these were due to the welding fumes in their workplace. ${ }^{13}$ Several other studies have highlighted the hazards automobile assembly workers are exposed to. ${ }_{8,9,10}$

Assessment of the level of knowledge of occupational hazards among a set of workers is an effort to find out whether they know they are exposed to any hazard in their workplace and if yes, the type of hazards and the work processes that constitute those hazards, the measures that can be taken to prevent or minimize such dangers. One might go further to assess the worker's source of knowledge, and even the factors that affect the level of knowledge of the workers. This study was aimed at revealing the determinants of the knowledge of workers regarding the occupational hazards in their workplace among production workers in two automobile assembly plants in Nigeria. It is a sequel to an earlier study which determined the level of knowledge of the same production workers regarding the occupational hazards in their workplace ${ }^{14}$

\section{Methodology}

Study Area: This study was carried out at two automobile assembly companies in Nigeria. The companies are represented as Plant A and Plant B because of an agreement with the management of the companies to maintain confidentiality in the publication of the findings of the study. The production department of Plant A is made up of the following sections: Body shop, Spray shop, Final finishing, Chassis assembly and Auto electrical section. There are 268 staff in the production department. The breakdown is as follows: Body shop (79), Spray shop (45), Final finishing (82), chassis assembly (40), Auto electrical section (22).

The production department of Plant B is divided into the following sections: Body shop, Trimeline, Rectification, Paint Shop and Chassis assembly. There are 50 staff in the production department, broken down as follows: Body $\operatorname{Shop(23),~Trimeline(7),~Rectification(9),~Paint~shop(7),~Chassis~}$ assembly(4).

Study Design: This study was a Cross-sectional, descriptive study.

Study Population: The study population comprises all the staff in the production department of the two companies.

Inclusion Criteria: Eligible respondents were workers in the production department of the automobile assembly companies who have worked in the production department for at least 6 months, because they were considered to have had enough exposure to the hazards and also would be able to 
give information on the situation of things in the companies. Only such workers who gave their consent were administered the questionnaire.

Exclusion Criteria: Production staff who have not worked for at least 6 months.Production staff that denied consent.Production staff that were on leave during the period of the data collection.

Sample Size Determination: Using the formula for determination of minimum sample size in a cross sectional study. ${ }^{15}$

For population $>10,000$

$$
\mathrm{n}=\underline{\mathrm{z}^{2} p q}
$$

$\mathrm{n}=$ the minimum sample size

$\mathrm{z}=$ the standard normal deviate $=1.96$

$\mathrm{p}=$ the proportion of the target population that have a particular characteristic. In this case $\mathrm{p}=0.46$ (proportion of workers in an automobile assembly plant in Kaduna that are exposed to the commonest occupational hazard (chemical fumes) in the plant according to the study. ${ }^{16}$

$$
\begin{aligned}
& \mathrm{q}=1-\mathrm{p}=1-0.46=0.54 \\
& \mathrm{~d}=\text { degree of accuracy }=0.05 \\
& \mathrm{n}=\frac{1.96^{2} \times 0.46 \times 0.54}{0.05^{2}}
\end{aligned}
$$$$
\mathrm{n}=\underline{3.84 \times 0.25}
$$$$
0.0025
$$

$\mathrm{n}=\underline{0.96}$

$$
0.0025
$$

$\mathrm{n}=384$

But the population of the workers is 318 which is less than 10,000 , hence a step further is taken to calculate for population less than 10,000 as stated in the formula thus ${ }^{15}$ :

$\mathrm{nf}=$

$$
\frac{n}{1+\frac{(n)}{N}}
$$

where $\mathrm{nf}=$ minimum sample size when population is less than 10,000

$\mathrm{n}=$ minimum sample size when population is greater than 10,000

$\mathrm{N}=$ the population size

Applying the respective values:

$$
\begin{aligned}
\mathrm{nf} & =\frac{384}{1+\frac{(384)}{318}} \\
& =\frac{384}{1+1.21} \\
& =\frac{384}{2.21} \\
\mathrm{nf} & =174
\end{aligned}
$$


Hence the minimum sample size is 174 . But in order to increase the power of the study, all the 318 production workers in the two automobile assembly companies were sampled.

Sampling Technique: Total population sampling was used because all the production staff (318), in the two automobile assembly companies were administered questionnaires.

Instruments of Data Collection: A semi-structured interviewer-administered questionnaire was purposely designed for this study. It was pre-tested and appropriate corrections made.

Data Entry and Analysis: Data collected was analysed with the aid of the computer software: Statistical Package for Social Sciences (SPSS) Version 20.Frequency distributions and percentages of all relevant variables were represented in tables and charts for easy appreciation.

Ethical Consideration: Ethical approval was obtained from the Nnamdi Azikiwe University Teaching Hospital Ethical Committee (NAUTHEC). Permission to carry out this study was obtained from the management of the companies. Before the questionnaire was administered to each respondent, the concept and purpose of the study was carefully explained to the respondent. The respondents were also assured of confidentiality. Only consenting workers were administered questionnaires. The respondents also signed an informed consent form.

Limitations: Some of the workers felt reluctant to volunteer information. This was overcome by carefully assuring them of confidentiality.

\section{RESUlts}

Table1. Socio-demographic characteristics of respondents

\begin{tabular}{|c|c|c|}
\hline Variables & Frequency $(\mathbf{N}=318)$ & Percentage \\
\hline \multicolumn{3}{|l|}{ Company } \\
\hline Plant B & 50 & 15.7 \\
\hline Plant A & 268 & 84.3 \\
\hline \multicolumn{3}{|l|}{ Sex } \\
\hline Male & 308 & 96.9 \\
\hline Female & 10 & 3.1 \\
\hline \multicolumn{3}{|l|}{ Age (years) } \\
\hline$\leq 20$ & 36 & 11.3 \\
\hline $21-25$ & 96 & 30.2 \\
\hline $26-30$ & 119 & 37.4 \\
\hline $31-35$ & 35 & 11.0 \\
\hline $36-40$ & 5 & 1.6 \\
\hline$>40$ & 27 & 8.5 \\
\hline Mean (SD) & $27.88(7.28)$ & \\
\hline \multicolumn{3}{|l|}{ Marital status } \\
\hline Single & 229 & 72.0 \\
\hline Married & 86 & 27.0 \\
\hline Widowed & 2 & 0.6 \\
\hline Separated & 1 & 0.3 \\
\hline \multicolumn{3}{|c|}{ Highest level of Education } \\
\hline No formal education & 0 & 0 \\
\hline Primary education & 0 & 0 \\
\hline Secondary education & 299 & 94.0 \\
\hline Tertiary education & 19 & 6.0 \\
\hline \multicolumn{3}{|c|}{ Duration of employment (yrs) } \\
\hline $1-2$ & 141 & 44.3 \\
\hline $3-4$ & 141 & 44.3 \\
\hline $5-6$ & 3 & 0.9 \\
\hline $7-8$ & 4 & 1.3 \\
\hline $9-10$ & 10 & 3.1 \\
\hline$>10$ & 19 & 6.0 \\
\hline Mean (SD) & $3.62(4.67)$ & \\
\hline
\end{tabular}

Table 1 shows the socio-demographic characteristics of the respondents. Out of the 318 respondents, $50(15.7 \%)$ were workers in Plant B, while $268(84.3 \%)$ were workers in Plant A. There were 308 (96.9\%) males and only $10(3.1 \%)$ females. The commonest age group was the 26-30 years age group, $119(37.4 \%)$ while the least common age group was the 36-40 years age group $5(1.6 \%)$. The mean 
age was 27.88 years with a standard deviation of \pm 7.28 years. There were $229(72.0 \%)$ single respondents, while $86(27.0 \%)$ were married. Majority of the respondents had secondary education $299(94.0 \%)$, while $19(6.0 \%)$ had tertiary education. None of the respondents had no formal education. The proportion $141(44.3 \%)$ have worked for 3 to 4 years. Only $3(0.9 \%)$ respondents have worked for 5 to 6 years. The mean number of years of working in the companies was 3.62 years $( \pm$ 4.07 years).

Table2. Association between respondents' age and knowledge of hazards in their workplace

\begin{tabular}{|c|c|c|c|c|c|}
\hline \multirow[t]{3}{*}{ Variables } & \multicolumn{3}{|c|}{ Age (years) } & \multirow[t]{2}{*}{$\mathbf{X}^{2}$} & \multirow[t]{2}{*}{ p-value } \\
\hline & \multicolumn{3}{|c|}{ Frequency $(\%)$} & & \\
\hline & $\leq 25$ years & $>25$ years & Total & & \\
\hline \multicolumn{6}{|c|}{$\begin{array}{l}\text { Respondents that were aware } \\
\text { of hazards in their workplace }\end{array}$} \\
\hline Yes & $121(39.8)$ & $183(60.2)$ & $304(100.0)$ & 8.285 & 0.00 \\
\hline No & $11(78.6)$ & $3(21.4)$ & $14(100.0)$ & & \\
\hline \multicolumn{6}{|c|}{$\begin{array}{l}\text { Occupational hazards workers } \\
\text { identified in their workplace } \\
\qquad(\mathrm{N}=304)\end{array}$} \\
\hline Machine accidents & $97(39.1)$ & $151(60.9)$ & $248(100.0)$ & $* 2.146$ & 0.06 \\
\hline Metal dusts & $58(31.5)$ & $126(68.5)$ & $184(100.0)$ & & \\
\hline Excessive noise & $38(22.5)$ & $131(77.5)$ & $169(100.0)$ & & \\
\hline Gases \& fumes & $47(28.3)$ & $119(71.7)$ & $166(100.0)$ & & \\
\hline Bad working positions & $46(31.1)$ & $102(68.9)$ & $148(100.0)$ & & \\
\hline Electrocution & $52(35.6)$ & $94(64.4)$ & $146(100.0)$ & & \\
\hline Excessive heat & $39(33.6)$ & $77(66.4)$ & $116(100.0)$ & & \\
\hline Foreign body in the eye & $32(36.8)$ & $55(63.2)$ & $87(100.0)$ & & \\
\hline Corrosives & $21(32.3)$ & $44(67.7)$ & $65(100.0)$ & & \\
\hline Falling objects & $0(0.0)$ & $55(100.0)$ & $55(100.0)$ & & \\
\hline Hot liquid & $1(3.1)$ & $31(96.9)$ & $32(100.0)$ & & \\
\hline Slippery floor & $0(0.0)$ & $29(100.0)$ & $29(100.0)$ & & \\
\hline
\end{tabular}

*Likelihood ratio used when $>20 \%$ cells have expected values $<5$.

Table3. Association between respondents' age and their knowledge of occupational illnesses/injuries that can occur in their workplace.

\begin{tabular}{|c|c|c|c|c|c|}
\hline \multirow{3}{*}{$\begin{array}{l}\text { Occupational illnesses/ injuries that } \\
\text { can occur in their workplace }\end{array}$} & \multicolumn{3}{|c|}{ Age (years) } & \multirow[t]{2}{*}{$\mathrm{X}^{2}$} & \multirow{2}{*}{$\begin{array}{c}\text { p- } \\
\text { valu } \\
\text { e }\end{array}$} \\
\hline & \multicolumn{3}{|c|}{ Frequency $(\%)$} & & \\
\hline & $\leq 25$ years & $>25$ years & Total & & \\
\hline Waist pain & $94(38.5 \%)$ & $150(61.5 \%)$ & $244(100.0)$ & $* 2.111$ & 0.06 \\
\hline cut or laceration & $74(36.5)$ & $129(63.5)$ & $203(100.0)$ & & \\
\hline Eye problems & 77 (38.3) & $124(61.7)$ & $201(100.0)$ & & \\
\hline Hearing problems & $47(33.1)$ & $102(68.5)$ & $149(100.0)$ & & \\
\hline Respiratory problems & $47(33.1)$ & $95(66.9)$ & $142(100.0)$ & & \\
\hline Sprain & $48(39.0)$ & $75(61.0)$ & $123(100.0)$ & & \\
\hline Electrocution & $29(32.2)$ & $61(67.8)$ & $90(100.0)$ & & \\
\hline Burns & $14(18.4)$ & $62(81.6)$ & $76(100.0)$ & & \\
\hline Skin disease & $0(0.0)$ & $21(100.0)$ & $21(100.0)$ & & \\
\hline Fracture & $1(9.1)$ & $10(90.9)$ & $11(100.0)$ & & \\
\hline Lead poisoning & $0(0.0)$ & $11(100.0)$ & $11(100.0)$ & & \\
\hline Cancers & $0(0.0)$ & $10(100.0)$ & $10(100.0)$ & & \\
\hline Traumatic amputation of a digit & $0(0.0)$ & $7(100.0)$ & $7(100.0)$ & & \\
\hline
\end{tabular}

Likelihood ratio used when $>20 \%$ of cells have expected value $<5$

\section{Statistically significant}

Table 2 shows the association between the respondents' age and their knowledge of hazards in their workplace. A higher proportion of the respondents who were aware of hazards in their workplace were $>25$ years of age $183(60.2 \%)$ compared with those who were $\leq 25$ years of age. This difference 
was statistically significant $\left(\mathrm{X}^{2}=8.285, \mathrm{p}=0.00\right)$. However there was no statistically significant difference in the type of hazards identified by the respondents in the different age groups.

Table 3 shows the association between the respondents' age and their knowledge of occupational illnesses/injuries that can occur in their workplace. A higher proportion of the respondents that identified each hazard was $>25$ years of age compared with those that were $\leq 25$ years of age. However the difference was not statistically significant $\left(\mathrm{X}^{2}=2.111, \mathrm{p}=0.06\right)$.

Table 4.Association between respondents' age and knowledge of measures that can be taken to prevent occupational illnesses/injuries in their workplace.

\begin{tabular}{|c|c|c|c|c|c|}
\hline \multirow{3}{*}{$\begin{array}{l}\text { Measures that can be taken to } \\
\text { prevent } \\
\text { occupational illnesses/injuries }\end{array}$} & \multicolumn{3}{|c|}{ Age (years) } & \multirow[t]{3}{*}{$\mathbf{X}^{2}$} & \multirow[t]{2}{*}{ p-value } \\
\hline & \multicolumn{3}{|c|}{ Frequency (\%) } & & \\
\hline & $\leq 25$ years & $>25$ years & Total & & \\
\hline Provision of medical/first aid services & $82(33.2)$ & $165(66.8)$ & $247(100.0)$ & 2.490 & 0.09 \\
\hline Use of PPDs & 99 (41.4) & $140(58.6)$ & $239(100.0)$ & & \\
\hline Warning signs at strategic locations & $14(25.0)$ & $42(75.0)$ & $56(100.0)$ & & \\
\hline Pre-employment medical examinations & $4(9.8)$ & $37(90.2)$ & $41(100.0)$ & & \\
\hline Periodic medical examination & $6(16.7)$ & $30(83.3)$ & $36(100.0)$ & & \\
\hline Good house keeping & 4914.30 & $24(85.7)$ & $28(100.0)$ & & \\
\hline Periodic trainings on $\mathrm{OSH}$ & $4(15.4)$ & $22(84.6)$ & $26(100.0)$ & & \\
\hline Isolation of dangerous areas & $5(20.0)$ & $20(80.0)$ & $25(100.0)$ & & \\
\hline Periodic inspection of workplace & $5(20.0)$ & $20(80.0)$ & $25(100.0)$ & & \\
\hline $\begin{array}{l}\text { Substitution of harmful raw materials } \\
\text { with harmless ones }\end{array}$ & $4(19.0)$ & $17981.0)$ & $21(100.0)$ & & \\
\hline
\end{tabular}

Table5. Association between respondents' age and their knowledge of PPDs

\begin{tabular}{|c|c|c|c|c|c|}
\hline \multirow{3}{*}{$\begin{array}{c}\text { PPDs workers considered necessary } \\
\text { in their workplace }\end{array}$} & \multicolumn{3}{|c|}{ Age (years) } & \multirow[t]{3}{*}{$\mathrm{X}^{2}$} & \multirow[t]{2}{*}{ p-value } \\
\hline & \multicolumn{3}{|c|}{ Frequency $(\%)$} & & \\
\hline & $\leq 25$ years & $>25$ years & Total & & \\
\hline Aprons/overalls & $85(34.8)$ & $159(65.2)$ & $244(100.00$ & 2.940 & 0.09 \\
\hline Eye goggles & 100 941.5) & $141(58.5)$ & $241(100.0)$ & & \\
\hline Boots & $75(31.5)$ & $163(68.5)$ & $238(100.0)$ & & \\
\hline Hand gloves & $71(31.6)$ & $154(68.4)$ & $225(100.0)$ & & \\
\hline Face mask & $75(41.0)$ & $108(59.0)$ & $183(100.0)$ & & \\
\hline Helmets & $41(47.1)$ & $46(52.9)$ & $87(100.0)$ & & \\
\hline Ear plugs/muffs & $13(21.3)$ & 48 (78.7) & $61(100.0)$ & & \\
\hline Respirators & $2(95.4)$ & 35 (94.6) & $37(100.0)$ & & \\
\hline
\end{tabular}

Table 6. Association between respondents' marital status and knowledge of occupational illnesses/injuries that can occur in their workplace

\begin{tabular}{|c|c|c|c|c|c|}
\hline \multirow{2}{*}{$\begin{array}{c}\text { Occupational illnesses/injuries that } \\
\text { can occur in their workplace }\end{array}$} & \multicolumn{3}{|c|}{ Marital status } & \multirow{2}{*}{ 放 } & \multirow{2}{*}{ p-value } \\
\cline { 2 - 4 } & \multicolumn{3}{|c|}{ Frequency (\%) } & & \\
\cline { 2 - 4 } & Never married & Others & Total & & \\
\hline Waist pain & $166(68.9)$ & $76(31.1)$ & $244(100.0)$ & 1.590 & 0.21 \\
\hline Cut/laceration & $162(79.8)$ & $41(20.2)$ & $203(100.0)$ & & \\
\hline Eye problems & $177(88.1)$ & $24(11.9)$ & $201(100.0)$ & & \\
\hline Hearing problems & $121(81.2)$ & $28(18.8)$ & $149(100.0)$ & & \\
\hline Respiratory problems & $113(79.6)$ & $29(20.4)$ & $142(100.0)$ & & \\
\hline Sprain & $103(83.7)$ & $20(16.3)$ & $123(100.0)$ & & \\
\hline Electrocution & $71(78.9)$ & $19(21.1)$ & $90(100.0)$ & & \\
\hline Burns & $59(77.6)$ & $17(22.4)$ & $76(100.0)$ & & \\
\hline Skin disease & $12(57.1)$ & $9(42.9)$ & $21(100.0)$ & & \\
\hline Fracture & $0(0.0)$ & $11(100.0)$ & $11(100.0)$ & & \\
\hline Lead poisoning & $1(9.1)$ & $10(90.9)$ & $11(100.0)$ & & \\
\hline Cancers & $1(10.0)$ & $9(90.0)$ & $10(100.0)$ & & \\
\hline Traumatic amputation of a digit & $0(0.0)$ & $7(100.0)$ & $7(100.0)$ & & \\
\hline
\end{tabular}

Table 4 shows the association between respondents' age and their knowledge of measures that can be taken to prevent occupational illnesses/injuries in their workplace. A higher proportion of the respondents who identified preventive measures were $>25$ years of age compared with those that were $\leq 25$ years of age. However the difference was not statistically significant $\left(X^{2}=2.490, p=0.09\right)$. 
Table 5 shows the association between respondents' age and their knowledge of PPDs. A higher proportion of the respondents that identified PPDs were $>25$ years of age compared with those that were $\leq 25$ years of age. However the difference was not statistically significant $\left(X^{2}=2.940, p=0.09\right)$

Table 6 shows the association between the marital status of the respondents and their knowledge of occupational illnesses/injuries that can occur in their workplace. A greater proportion of the respondents that identified the first nine occupational illnesses/injuries were never married, compared with other marital groups. Also the greater proportion of those that identified the remaining four occupational illnesses/injuries were of the other marital groups compared with those that were never married. However these differences were not statistically significant $\left(X^{2}=1.59, \mathrm{p}=0.00\right)$.

Table 7. Association between respondents' marital status and their knowledge of measures to prevent occupational illnesses/injuries

\begin{tabular}{|l|l|l|l|l|l|}
\hline \multirow{2}{*}{$\begin{array}{l}\text { Measures that can be taken to prevent } \\
\text { occupational illnesses/injuries }\end{array}$} & \multicolumn{3}{|c|}{ Marital status } & $\mathbf{X}^{2}$ & $\begin{array}{l}\text { p- } \\
\text { value }\end{array}$ \\
\cline { 2 - 6 } & \multicolumn{3}{|c|}{ Frequency (\%) } & & \\
\cline { 2 - 6 } & $\begin{array}{l}\text { Never } \\
\text { married }\end{array}$ & Others & Total & & \\
\hline Provision of medical/first aid services & $194(78.5)$ & $53(21.5)$ & $247(100.0)$ & 0.300 & 0.58 \\
\hline Use of PPDs & $158(66.1)$ & $81(33.9)$ & $239(100.0)$ & & \\
\hline Warning signs at strategic locations & $20(35.7)$ & $36(64.3)$ & $56(100.0)$ & & \\
\hline Pre-employment medical examinations & $9(22.0)$ & $32(78.0)$ & $41(100.0)$ & & \\
\hline Good house keeping & $6(21.4)$ & $22(78.6)$ & $28(100.0)$ & & \\
\hline Periodic trainings on OSH & $6(23.1)$ & $20(76.9)$ & $26(100.0)$ & & \\
\hline Isolation of dangerous areas & $10(40.0)$ & $15(60.0)$ & $25(100.0)$ & & \\
\hline Periodic inspection of workplace & $11(44.0)$ & $14(56.0)$ & $25(100.0)$ & & \\
\hline $\begin{array}{l}\text { Substitution of harmful raw materials } \\
\text { with harmless ones }\end{array}$ & $7(33.3)$ & $14(66.7)$ & $21(100.0)$ & & \\
\hline
\end{tabular}

Table 8.Association between respondents' marital status and knowledge of PPDs

\begin{tabular}{|l|l|l|l|l|l|}
\hline \multirow{2}{*}{$\begin{array}{l}\text { PPDs workess considered } \\
\text { necessy in their workplace }\end{array}$} & \multicolumn{3}{|c|}{ Marital status } & \multirow{2}{*}{$\mathbf{X}^{\mathbf{2}}$} & \multirow{2}{*}{ p-value } \\
\cline { 2 - 5 } & $\begin{array}{l}\text { Never } \\
\text { married }\end{array}$ & Others & Total & & \\
\hline Aprons/overalls & $190(77.9)$ & $54(22.1)$ & $244(100.0)$ & 1.950 & 0.16 \\
\hline Eye goggles & $198(82.2)$ & $43(17.8)$ & $241(100.0)$ & & \\
\hline Boots & $170(71.4)$ & $68(28.6)$ & $238(100.0)$ & & \\
\hline Hand gloves & $183(81.3)$ & $42(18.7)$ & $225(100.0)$ & & \\
\hline Face mask & $145(79.2)$ & $38(20.8)$ & $183(100.0)$ & & \\
\hline Helmets & $64(73.6)$ & $23(26.4)$ & $61(100.0)$ & & \\
\hline Ear plugs/muffs & $36(59.0)$ & $25(41.0)$ & $61(100.0)$ & & \\
\hline Respirators & $14(37.8)$ & $23(62.2)$ & $37(100.0)$ & & \\
\hline
\end{tabular}

Table 7 shows the association between respondents' marital status and their knowledge of measures to prevent occupational illnesses/injuries. A greater proportion of the respondents that identified provision of medical/first aid services were never married compared with the other marital groups. Also a greater proportion of the respondents who identified the use of PPDs were never married compared with those who were married. For each of the remaining measures identified, a greater proportion of the respondents that identified each measure was of the other marital groups compared with the never married group. However the differences were not statistically significant $\left(X^{2}=0.300 \mathrm{p}\right.$ $=0.58)$

Table 8 shows the association between respondents' marital status and their knowledge of PPDs. For each of the PPDs identified, a greater proportion of the respondents were never married. However the difference was not statistically significant $\left(\mathrm{X}^{2}=1.950, \mathrm{p}=0.16\right)$. 


\section{DisCUSSION}

This study aimed at identifying determinants of knowledge of occupational hazards and safety measures among the production staff of the two automobile assembly plants. This study is a sequel to an earlier study on the knowledge of occupational hazards and safety measures among the same production department workers. ${ }^{14}$ Our findings reveal thathere were more male respondents $(84.3 \%)$ than female respondents (15.7\%), similarly, in a car assembly plant in Kaduna, Nigeria, ${ }^{19}$ among the production staff, $71.8 \%$ were males and $28.2 \%$ were females. Also in apetroleum refinery at Kaduna, Nigeria $90 \%$ of the workers was males. ${ }^{17}$ In the United States it was reported that $74.1 \%$ of automobile assembly workers were males and $25.9 \%$ were females. ${ }^{18}$ Thismale predominance among factory workers may be because factory jobs are physically tasking hence females tend to avoid them. We also discovered that the commonest age group among the workers was the 26-30 years age group (37.4\%). This is unlike the finding at an automobile assembly company in Kaduna, Nigeria where the commonest age group was the 30-39 years age group. ${ }^{16}$ Also a study at a refinery in Kaduna reported that the commonest age group was the 35-39 years age group $(24 \%) .{ }^{17}$ However a similar finding was reported among stone quarry workers in Zaria, Nigeria where the commonest age group was the 25-29 years age group $(37.8 \%) .{ }^{20}$ Despite the differences in the commonest age groups, they all fell within the young and productive age groups.

We observed that majority of the respondents in our study were single (72.0\%). This is similar to the finding among welders in Kaduna, Nigeria where majority of the workers $(63.3 \%)$ were single. ${ }^{21}$ Unlike our study, it was reported that majority of the workers $(52.7 \%)$ in an automobile assembly plant in Kaduna, Nigeria were married, ${ }^{19}$ also majority of the workers $(72.0 \%)$ in a refinery at Kaduna were married.Also, majority of the workers $(67.0 \%)$ in a sawmill in Ile-Ife, Nigeria were married. ${ }^{22}$ This higher proportion of single respondents in this study may be because majority of the respondents are males and they are in the younger age group compared to the older age groups in the other studies cited.

Furthermore, a higher proportion of the respondents had secondary education (94.0\%) similarly majority of the welders in Kaduna $(62.7 \%)$ had secondary education, ${ }^{21}$. This was also the situation in Benin City, Nigeria where majority $(44.37 \%)$ of the welders had secondary education. ${ }^{23}$ In contrast, majority $(50.0 \%)$ of the workers in an automobile assembly plant in Kaduna had tertiary education. ${ }^{16}$ This is also the situation in a refinery in Kaduna, where majority $(78.0 \%)$ of the workers had tertiary education. ${ }^{17}$ The higher proportion of secondary school certificate holders in this study may be because the production workers are semi-skilled staff who are employed with senior school certificate and then trained to work under the supervision of few engineers.

It is worthy of note that majority $(44.3 \%)$ of the production staff in these two automobile assembly plants had worked for 3-4 years. This contrasts the finding among welders in Kaduna, Nigeria where majority $(36.4 \%)$ have worked for $5-9$ years. ${ }^{21}$ Also majority $(28.6 \%)$ of the welders in Benin city Nigeria have worked for 16-20 years. ${ }^{23}$ Similarly, majority $(47.3 \%)$ of the workers in a stone quarry in Kaduna, Nigeria have worked for 12-59 years. ${ }^{20}$ The relatively short duration of service of the respondents in this study may be explained by the fact that the two automobile assembly plants started operations just a few years ago.

Majority (32.1\%) of the respondents in our study work in the Body shop section. This is unlike the situation at an automobile assembly plant in Kaduna, Nigeria where majority (25.5\%) of the respondents was in the assembly unit. ${ }^{19}$ This difference is probably due to the differences in the organization of the companies and the mix of mechanization of processes.

Our findings show that a higher proportion of the respondents who were aware of hazards in their workplace were $>25$ years of age $183(60.2 \%)$ compared with those who were $\leq 25$ years of age. This difference was statistically significant $\left(\mathrm{X}^{2}=8.285, \mathrm{p}=0.00\right)$. However there was no statistically significant difference in the type of hazards identified by the respondents in the different age groups. This implies that age has an effect on the awareness of workplace hazards among the workers. Also a higher proportion of the respondents that identified each hazard was $>25$ years of age compared with those that were $\leq 25$ years of age. However the difference was not statistically significant $\left(\mathrm{X}^{2}=2.111\right.$, $\mathrm{p}=0.06$ ). This implies that age has no effect on the knowledge of the different types of hazards that can occur in their workplace. 
We explored the association between respondents' age and their knowledge of measures that can be taken to prevent occupational illnesses/injuries in their workplace. A higher proportion of the respondents who identified preventive measures were $>25$ years of age compared with those that were $\leq 25$ years of age. However the difference was not statistically significant $\left(X^{2}=2.490, p=0.09\right)$, meaning that age has no effect on the knowledge of safety measures among the respondents. Similarly there was no between respondents' age and their knowledge of PPDs. Though a higher proportion of the respondents that identified PPDs were $>25$ years of age compared with those that were $\leq 25$ years of age, the difference was not statistically significant $\left(X^{2}=2.940, p=0.09\right)$.

Another finding was that; there was no association between the marital status of the respondents and their knowledge of occupational illnesses/injuries that can occur in their workplace. Although a greater proportion of the respondents that identified the first nine occupational illnesses/injuries were never married, compared with other marital groups and the greater proportion of those that identified the remaining four occupational illnesses/injuries were of the other marital groups compared with those that were never married, these differences were not statistically significant $\left(X^{2}=1.59, p=0.00\right)$. Exploring marital status further, we found out that there was no association between respondents' marital status and their knowledge of measures to prevent occupational illnesses/injuries. This was demonstrated by the finding that despite the fact that a greater proportion of the respondents that identified provision of medical/first aid services were never married compared with the other marital groups, and a greater proportion of the respondents who identified the use of PPDs were never married compared with those who were married, the differences were not statistically significant $\left(\mathrm{X}^{2}=\right.$ $0.300 \mathrm{p}=0.58$ ). Furthermore, another finding was that marital status had no effect on the respondents' knowledge of PPDs, demonstrated by the finding that despite the finding that; for each of the PPDs identified, a greater proportion of the respondents were never married, the difference was not statistically significant $\left(X^{2}=1.950, p=0.16\right)$. These findings have demonstrated that age and marital status were not determinants for knowledge regarding occupational hazards and safety measures among automobile assembly workers.

\section{Conclusion}

This study has revealed that age and marital status were not determinants of knowledge regarding occupational hazards and safety measures among automobile assembly workers. In this era of evidence-based decision making, it becomes pertinent to explore more "suspected" determinants to really confirm whether they are actually determinants of the knowledge of occupational hazards and safety measures among automobile assembly plant workers. We therefore recommend that further studies be carried out on possible determinants of knowledge of occupational hazards and safety measures among automobile assembly workers.

\section{Competing Interests}

The authors hereby declare that there are no competing interests. We also declare thatthis study was part of a bigger study whichwas conducted in partial fulfillment of therequirements for the award of theFellowship of the National Postgraduate Medical College of Nigeria. Some parts of the bigstudy have been published ${ }^{14,24}$ while other parts are in different stages of theprocess ofpublication.

\section{REFERENCES}

[1] International Labour Organisation. ILO international safety and health conference 2013 Programme. 1st ed. Geneva: International Labour Organization; 2013: 40.

[2] International Labour Organization Governing Body. Decision on the third item on the agenda: Prevention of occupational diseases. Available online at http://www.ilo.org/gb/decisions/ Gb17decision/WCMS_207354/lang-en/index.hm.(Accessed on 25/11/13)

[3] Rosenstock L, Cullen M, Fingerhut M. Occupational health .In : Disease Control Priorities in developing countries. 2nd ed. New York: Oxford University Press; 2006: 1127 - 1146.

[4] Takala J. "Introductory report: Decent work - safe work". Paper presented at the 16th World Congress on Safety and Health, Vienna. May 272002.

[5] World Health Organization. Global health risks: mortality and burden of disease attributable to selected major risks. 1st ed. Geneva: World Health Organization; 2009: 62.

[6] Leigh JP. Economic burden of occupational injury and illness in the United States. Milibank Quarterly, 2011; 89(4): 728-772. 
[7] Eijkemans G. WHO and ILO joint effort on occupational health and safety in Africa. African Newsletter on occupational Health and safety, 2004; 14: 28-29.

[8] Shukor A. An assessment of occupational hazards and ergonomic risk factors on young male workers in Malaysia. Injury Prevention, 2010; 16(1): A1-A289.

[9] Zhang M, Zheng Y, Du X, Lu Y, Li W, Qi C, Wu Z. Silicosis in automobile foundry workers: a 29-year cohort study. Biomedical and Environmental Sciences, 2010; 23(2): 121-129.

[10] Lilies R, Valciukas JA; Kon S, Sarkosi L, Campbell C, Selikoff I. Assessment of lead health hazards in a body shop of an automobile assembly plant. American Journal of Industrial Medicine, 1982; 3: 33-51.

[11] Liu S, Liu J, Sun J. Survey of occupational hazards in an automobile manufacturing company. Journal of Environmental and occupational medicine, 2008; 3(1): 295-297.

[12] Attarchi MS, Koohpayeh J, Labbfinejad Y, Mohammadi S. Effect of exposure to low levels of organic solvent mixtures on colour vision. Journal of Medical Council of Islamic Republic of Iran, 2009; 27(3): 307-316.

[13] Sharifian S, Lokzadeh Z, Ahmad S, Aminian O. Pulmonary adverse effects of welding fume in automobile assembly welders. Acta Medica Iranica, 2011; 49(2): 98-102.

[14] Azuike EC, Ilika AL, Obi-Okaro AC, Adinma ED, Nwabueze SA, Nnebue CC. Occupational hazards in two automobile assembly plants in Nigeria: what do the workers know? Palgo Journal of Medicine and Medical Science, 2016; 3(5): 113-120.

[15] Araoye MO, Research methodology with statistics for health and social sciences. 1st ed. Ilorin: Nathadex Publishers; 2003: 117-120.

[16] Aliyu AA, Shehu AU, Singha P. Evaluation of occupational health services and hazards in a car assembly plant in Kaduna Nigeria. Port Harcourt Medical Journal, 2009; 3(1): 349-353.

[17] Aliyu AA, Saidu S. Pattern of occupational hazards and provision of occupational health services and safety among workers of Kaduna refinery and petrochemical company limited (KRPC), Kaduna, Nigeria. Continental Journal of Tropical Medicine,2011; 5: 1-5.

[18] Kobrosly RW, Meliker JR, Nriagu JO. Automobile industry occupations and bladder cancer: a population based case-control study in Southeastern Michigan, USA. Occup Environ Med, 2009; 66: 650-656.

[19] Aliyu AA, Shehu AU, Singha P. Evaluation of occupational health services and hazards in a car assembly plant in Kaduna Nigeria. Port Harcourt Medical Journal, 2009; 3(1): 349-353.

[20] Aliyu AA, Shehu AU. Occupational hazards and safety measures among stone quarry workers in Northern Nigeria. Nigerian Medical Practitioner, 2006; 50(2): 42-47.

[21] Sabitu K, Iliyasu Z, Dauda MM. Awareness of occupational hazards and utilization of safety measures among welders in Kaduna metropolis, Northen Nigeria. Annals of African Medicine, 2009; 8(1): 46-51.

[22] Faremi FA, Ogunfowokan AA, Mbada C, Olatubi MI, Ogungbemi AV. Occupational hazard awareness and safety practices among Nigerian sawmill workers. International Journal of Medical Science and Public Health, 2014; 3(10): 1244-1248.

[23] Isah EC, Okojie OH. Occupational health problems of welders in Benin City, Nigeria. Journal of Medicine and Biomedical Research, 2006; 5(1): 64-69.

[24] Azuike EC, Obi-Okaro AC, Ilika AL, Adinma ED, Nwabueze SA, Anene JO, Aniemena RC. Practice of safety measures by production workers in two Nigerian automobile assembly plants. Donnish Journals of Research in Environmental Studies, 2016; 3(4): 025-033. 